\title{
ETHYMOLOGY OF MEDICAL TERMS TRANSLATED INTO UZBEK FROM OTHER LANGUAGES
}

\author{
Suyunov Bakhodir \\ $2^{\text {nd }}$ year Doctoral Student of the National University of Uzbekistan named after Mirzo Ulugbek, \\ Tashkent, Uzbekistan
}

Article DOI: https://doi.org/10.36713/epra8586

DOI No: 10.36713/epra8586

\begin{abstract}
This article of the author is devoted to the etymology of medical terms that have been introduced into the Uzbek language from other languages. It also discusses the vocabulary, socio-historical development of the Uzbek language, its relationship with other languages and the peculiarities of word acquisition. The article analyzes medical terms, mainly from Arabic to Uzbek. In the process of analysis, the origin and semantic features of these lexical units have been thoroughly studied theoretically and practically. In this regard, the author effectively used scientific sources in Uzbek and Russian languages, as well as various dictionaries and research papers, and expressed his scientific hypothesis. Instead, he drew relevant scientific conclusions on the subject by referring to examples and evidence that differentiate the same concepts and phenomena. In particular, the article describes the etymology and national-cultural features of medical terms borrowed from Arabic into Uzbek - linguoculturology on the basis of historical and synchronous, comparative and component analysis methods. For example, the use of the complication lexeme in the Uzbek language in the sense of a sign, trace, specific feature, which appeared or appeared after an event, is associated with modern medicine in the example of today's infectious, acute respiratory disease pandemic "covid-2019". Attention is also paid to the synonym of the complication lexeme in the Uzbek language and its homonym. Many such original examples can be cited from the article. So, all of the above in a sense determines the scientific-theoretical and practical value of this article.
\end{abstract}

KEYWORDS: etymology, semantics, grammar, structure, cell, masdar, sukun, uzv, cultural linguistics, component, content, lexeme, term, phraseme, neologism, respirator, pandemic, anomaly.

\section{INTRODUCTION}

Some of the terms in our language are Uzbek medical terms. At the same time, Uzbek medical terminology uses terms from foreign languages, including Chinese, Greek, Latin, Russian, Mongolian, Arabic, Tajik and others. Such international terms also contribute to the development of our native language.

The first comparative researcher of terms in the Turkish language was Mahmud Kashgari. The first examples of linguistic terms can be found in Mahmud Kashgari's Devonu lug'otit turk. In this play, along with Turkish words and terms, Arabic and Tajik words and terms are also studied. In his time, he not only collected terms, words and terms from different dialects of the Turkic language, but also gave them scientific interpretations and commentaries.
In the current period of socio-economic and scientific-technical changes, new words and concepts are emerging in direct connection with the development of society. These, in turn, create new terms in our language. The range of meanings of a number of lexemes that have been used in the past is expanding and gaining new meaning.

Therefore, today a more in-depth study of practical and theoretical issues of terminology, the creation of Uzbek alternatives to terms, the regulation of their use on the basis of the laws of language has become a task of national importance. A more in-depth study of our native language, its internal and external capabilities, a comprehensive study of current issues of terminology is especially important now.

The study and research of semantically separate groups of medical terms learned in Uzbek from other 


\section{EPRA International Journal of Research and Development (IJRD)}

languages, in particular Arabic, plays an important role in the development of the Uzbek language today.

\section{METHODOLOGY}

Systematic, etymological, historical and synchronous analysis, comparative and component analysis, logical and content analysis methods were used in the research process.

\section{EMPIRICAL ANALYSIS}

A variety of nations, nationalities and peoples of the world, and their languages are different. There are more than 5,000 languages on earth, of which only about 500 have been studied. Forty of the world's languages have excellent oral and written forms. Among these 40 languages is Uzbek.

Uzbek is one of the oldest languages in the world. According to estimates, Uzbek is one of the richest languages in the world in terms of vocabulary and vocabulary. Currently, there are more than 1 million words and concepts in the Uzbek language. According to some sources, there are about 1.4-1.6 million words in Uzbek $^{1}$.

The 5-volume explanatory dictionary of the Uzbek language explains only 80,000 words that have been mastered in our literary language. Apparently, we have not yet been able to cover about 10 percent of the words in our language in dictionaries.

Uzbek language stands out among the world languages with its vocabulary, diversity of meanings, different semantic transitions and unique word formation. To date, it has gone through many historical processes, long stages of internal and external development. Sometimes living as a dominant language, and sometimes as a dependent language, he has served and continues to serve our nation - the Uzbek people.

Sometimes as a short-term state language, sometimes as a secondary language recognized by its people, it has become a human need. For hundreds of years, the Arabs, then the Mongols and the Persians, and then the Russians invaded, but the Uzbek language, as its own people, as a tolerant language, developed in all directions, sometimes openly, sometimes secretly.

In October 1989, the Uzbek language gained the status of the state language of the Republic of Uzbekistan.

In the course of this long historical and gradual development, the Uzbek language has learned many words from other languages, and, conversely, the Uzbek language has enriched the world's languages with many new words and terms, phrases and neologisms. The world has made and continues to make a huge

\footnotetext{
${ }^{1}$ Bobojonov M. About world languages. - Tashkent: "Muharrir", 2010. $8-\mathrm{p}$.
}

contribution to the system of communication and information.

Today, the vocabulary of the Uzbek language, along with the layer of Turkish words, also includes a layer of words from other languages, which includes Chinese, Arabic, Mongolian, Persian, Russian and other languages. The inclusion of such words in the Uzbek (Turkish) dictionary dates back to the time when Islam entered Central Asia and passed to the Uzbek language mainly directly (from sources written in Arabic) or indirectly (from sources written in Persian) ${ }^{2}$.

As noted above, there are many Arabic words among lexical units, including terms learned from other languages. Among them are medical terms learned from these foreign languages.

It should be noted that the words assimilated into the Uzbek language, in particular, the Arabic medical terms are not taken exactly in terms of sound, but to a certain extent Uzbekized, and in many cases adapted to the system of sounds of the Uzbek language. Also, in the analysis of the etymology of words and terms, given the current requirements, taking into account the possibilities of computer technology, the sounds in the acquired words are expressed in Latin letters.

Based on the above, the analysis of medical terms borrowed from Arabic into Uzbek and their written (graphical) description was based on the "Etymological Dictionary of the Uzbek language" (Sh. Rahmatullaev, 2003).

\section{Medical terms learned from Arabic can be} semantically divided into 4 :

The first - names of organs of the human body;

The second - names of diseases related to the human body (organism);

The third - the names of specialists who work with the human body;

The fourth - terms used in the diagnosis and treatment of diseases related to the human body.

\section{1). Names of organs of the human body}

A'zo - "a part of the body of a human or other creature". This Arabic word has the form a'dă (un) (Kh.Baranov, Arabic-Russian Dictionary (ARS), 523); In the Uzbek language, the fathali hamza was replaced by the a sound, the dzad sound by the $\mathrm{z}$ sound, the silent 'ayn was replaced by the' (subtraction) sign, the long ă vowel was replaced by the o vowel, and the ayn at the end of the word was omitted: a'dă' $\rightarrow \mathbf{a}^{\prime} \mathbf{z a ̆} \rightarrow$ as an a'zo. The word is a plural form of the word organ, which originally means "a part of the body that performs a function" (ARS, 521). From this word in the Uzbek language is derived the abstract name of membership (O'TEL, 56).

\footnotetext{
${ }^{2}$ Рахматуллаев Ш. Ўзбек тилининг этимологик луғати. - Тошкент:

"Университет", 2003. 3-б.
} 


\section{EPRA International Journal of Research and Development (IJRD)}

BADAN - "the integral surface of the body of a human or other creature". This word has the form of the Arabic badan (un) (ARS, 61); "well physique" is the masdar of Chapter I of the verb baduna, which means "well physique" (A. Kovalev, Textbook of the Arabic language (UAY), 568), "to the integrity of the human body" and the compound word (badantarbiya) physical education is formed on the basis of this meaning. The word body (badan) later came to mean "the surface of the body": My body trembled (OTIL, I, 70).

In Uzbek, the words organ (a'zo) and body (badan) are also used together. In such places the words organ (a'zo) and body (badan) are used to mean a whole body or all the organs of the human body. For example, for several months my whole body (a'zoyi badan) ached.

In addition to the meaning of a part of the human body, the a'zo lexeme also means to join an organization or society, to become a member of it. For example, he is a member of the Writers' Union of Uzbekistan.

JASAD - this Arabic word has the form çasad (un) (ARS, 129); is the masdar of Chapter I (UAYa), 568), which in Arabic (also in Tajik) means body "gavda", "jussa" (ARS, 129); Tajik-Russian Dictionary (TzhRS, 513); In the Uzbek language, this word has a figurative meaning and serves to mean "corpse" (OTIL, I, 108).

In the Uzbek language, the lexeme of the body is used in the sense of appearance, body, body, and also in the figurative sense of the dead, the body of the dead, the body, the corpse. For example, Cholning peshanasi tor va jussasi juda kichkina edi; O'lgandan keyin tog'amning jasadini Moskvadan maxsus yashikka solib olib kelishdi. The old man's forehead was narrow and his body very small; After his death, my uncle's body was brought from Moscow in a special box.

KIFT - the word originally has the forms katf (un), katif (un), kitf (un) in Arabic (APC, 677); The kitf form in Uzbek was adopted by substituting tf sounds: kitf $\rightarrow$ kift. As a masdar of Chapter I, which is formed from the plural verb katafa meaning "tied his hands" (ARS, 677). (N.Ibragimov, Arabic Grammar (ATG), 142), learned from Arabic to Uzbek the meaning of "shoulder" of the human body (OTIL, I, 389).

The word kitf in Arabic was introduced into Uzbek through a certain sound change, i.e. sound exchange: kitf $\rightarrow$ kift. The last consonants in this word have been replaced. The Arabic verb katafa - "tied his hands" - is derived into the Uzbek word kift - "shoulder". Here we can also see the peculiarities of the Uzbek language in terms of word acquisition. Here are some more examples:

ME'DA - This word, which was borrowed from Arabic into Uzbek, has its original form of mi'dat (un) (APC, 760); In Uzbek, it is accepted to replace the vowel $\mathrm{i}$ with the vowel $\mathrm{u}(\mathrm{e})$, to put the sign '(subtraction) instead of the silent ayn, and to leave the sound $t$ at the end of the word: mi'dat $\rightarrow$ me'da. It is a noun made of the verb mu'idah (ARS, 760) meaning "stomach ache" (UAYa, 499), originally means "stomach" (ARS, 760), in Uzbek it is used in the sense of "digestive organ", "digestive activity" (OTIL, I, 461).

The Arabic word mu'ida - "stomach ache" - is derived into the Uzbek word stomach - meaning "stomach".

In the Uzbek language, the gastric lexeme is also a homolexema and is a separate lexical unit. The lexeme me'da I I is used to mean a part of the human body "one of the digestive organs", "stomach".

Me'da II lexeme, Arabic for "disease that causes white or colored spots on the skin," is the name of such a disease. The disease is associated with inflammation of the gastric mucosa and is also referred to as gastric catarrh. Disease associated with a violation of the composition (norm) of digestive juice produced in various glandular cells of the gastric mucosa ${ }^{3}$.

Both lexemes belong to the noun and are related to the noun, i.e. the human organ and the common name of the disease. The word me'da is also used in Uzbek in such figurative senses as "to touch", "to dislike", "to bite"., for example, Hozir bu boyvachchangiz ham me'daga zig'ir yog'dek tegib turibdi. Now this "rich man" is touching your stomach like flaxseed oil (Hamza, The Case of Maysara $)^{4}$.

HUJAYRA - this Arabic word has the form huchayrat (un) (ARS, 157); In Uzbek, the consonant hoyi hutti was replaced by the consonant $h$, and the $t$-sound at the end of the word was dropped: h̆uçayrat $\rightarrow$ хужайра. Haçara the word given in the article of the verb is said to mean "separate room", "cell", "cell" in Arabic (ARS, 157); adopted in the Uzbek language with the final meaning (OTIL, II, 709; OTEL, 595).

The lexeme hujayra is a tiny body or organ present in the structural structure of the body of a human or living being that ensures its survival, vitality. It is known in science that the amount of water in the cell of a young organism is higher than in an old one. In addition to water, each cell contains other trace elements. For example, Teri ustini qoplagan hujayralar asta-sekin halok bo'ladi The cells that cover the surface of the skin gradually die (N.Ismailov, "Patient care").

In Uzbek, the word xujayra is used as a xujra meaning "separate room", "home". For example, Bolaligim mana shu kichik hujrada o'tgan. Men o'zimga yana bir hujra sotib oldim kabi. My childhood was spent in this small room. It's like I bought myself another room.

\footnotetext{
${ }^{3}$ Саломатлик энциклопедияси. - Тошкент: “Матбуот”, 1985, 264 265-б.

${ }^{4}$ Ўзбек тилининг изохли луғати. - Москва: 1981, 462-б.
} 


\section{EPRA International Journal of Research and Development (IJRD)}

\section{2). Names of diseases related to the human body (organism)}

ASABIY (nervous) - " a disease that quickly heats up and catches". The word has the Arabic form 'ashabiyy' (un) (ARS, 518); In Uzbek, the fathali ayn sound was replaced by the a sound, the sad sound by the s sound, and one of the uu sounds at the end of the word was dropped.: bašabiyy $\rightarrow$ asabiy. The word is a relative adjective derived from the Arabic word for asab (q.) - iyy (flour) (ATG, 48), which has several meanings. The main meaning of the Uzbek language is "to become hot and irritable" (OTIL, I, 56). In the Uzbek language from this quality are formed verbs asabiylan, asabiylash (Sh. Rahmatullaev, Etymological Dictionary of the Uzbek language (O'TEL), 42).

The asabiy lexeme in Uzbek is often applied to a person or animal who is constantly nervous, that is, angry. For example, Mahkamning ko'zlari kosasidan chihib ketguday chaqchaygan, qonsiz yuzidagi muskullar asabiy uchar edi The muscles in his bloodless face were flying nervously, his eyes squinting out of his cup. (P. Kadyrov, "Three roots"). This medical term actually refers to the general name of the disease. That is, a person who has a defect or defect in the nervous system. a person who is suddenly hot-tempered, irritable, upset, and angry at all sorts of trivial things. Such a disease can be congenital (hereditary - passed from parent to child) or acquired. Nervousness is an abnormal condition in humans that occurs as a result of a disorder of the nervous system.

ASORAT - "the effect, sign of a condition or disease". This Arabic word has the form asarat (flour) (ARS, 24); It was adopted in Uzbek by substituting the fathali hamza for the a sound, the se sound for the $\mathrm{s}$ sound, and the long ă sound for the o sound: bašărat $\rightarrow$ asarat $\rightarrow$ asorat. The word is a reference to Chapter I of the verb ashara (ARS, 23), which originally means "affected" (UAYa, 568; ARS, 23). residue "means: a complication of colds, like a complication of" covid "(OTIL, I, 58).

From the Arabic verb asara - "affected", from the verb meaning "residue" in the Uzbek language complication - an abstract noun meaning "illness, an accident, condition or negative balance of activity." The lexeme asorat is used in the Uzbek language in the sense of a sign, a trace, a specific feature that remains after or appears after something-event. It is natural for a character or trace to remain after any event. In particular, the infectious, acute respiratory disease called covid2019 today causes various serious complications such as muscle and joint pain, sputum production, changes in blood pressure, high blood sugar, fatigue, loss of appetite.

It is also widely used in the Uzbek language as a synonym for the complication lexeme, its abbreviated form - the word work. For example, a month later there was no trace of the disease. The word "Asar" is a common word in the Uzbek language, it has an example of creativity, the meaning of the book.

BASIR - "eye disorder". The word is Arabic and has the form bashír (un) (ARS, 74); It was adopted in Uzbek by replacing the sad sound with the s sound and the long i sound with the short i sound: bašïr $\rightarrow$ basir. This word is an original adjective derived from the verb bashira (ARS, 73), which means "saw", "gazed" (ATG, 43). Means "good eyesight" (ARS, 74). This word is included as such a meaningful word in (Tajik-Russian Dictionary (TjRS), 50), (B.Miller, Persidsko-Russian Dictionary (PRS), 69). The Explanatory Dictionary of the Uzbek Language (OTIL, I, 83) also states in parentheses that the word originally means "seeing", "seeing", but in practice it means "blind", "blind". Such a situation may have occurred under the influence of a reverse curse, such as the "basir bolgur", which is found in women's speech: As a result of the misunderstanding of "ko'radigan bolgur", the meaning of "ko'rmaydigan bolgur" was formed, and on this basis, the meaning of "blind" was added to the word basir.

The peculiarity of the Basir lexeme is that in Arabic it is an original adjective meaning "good eyesight", but in modern Uzbek literary language it means "blind", "no eyesight", "blinded". It is rare for such a reflection to occur in language.

VABO - The name "infectious disease that causes mass death." This Arabic word has the form vabă (un) (ARS, 869); In Uzbek, it is accepted to change the vowel ă to the vowel and to leave the hamza at the end of the word: vabăb $\rightarrow$ vabă $\rightarrow$ vabo. The word is originally derived from the verb vabi'a (ARS, 869), which means "afflicted with plague" (UAYa, 568), and means "plague", "plague" (OTIL, I, 169).

The lexeme of vabo is a common name for the disease and is used in Uzbek to refer to all types of diseases that cause mass destruction. In fact, (vabo) plague is an acute infectious disease that is accompanied by dehydration of the body, which quickly kills a person and is one of the most dangerous intestinal diseases. For example, Ochlik orqasidan vabo keldi. Och, bir burda nonga muhtoj, qip-yalang'och bo'lib qolgan xalq bittalab, o'ntalab emas, yuztalab, qishloqlab o'la boshladi The plague followed the famine. Naked, hungry, and in need of a loaf of bread, and the rest of the people, not one, ten, clans, villages began to die (S. Aniy, "Qullar" "slaves").

The lexeme of vabo (plague) is also used in a figurative sense to refer to unfortunate events such as disaster.

VASVOS - "insanity, a disease associated with doing whatever comes to mind". This word has the form vasvăs (un) in Arabic (ARS, 889); Accepted in the Uzbek language by substituting the vowel $\breve{a}$ for the vowel: vasvăs $\rightarrow$ vasvăs $\rightarrow$ vasvos. The word is 


\section{SJIF Impact Factor 2021: 8.013| ISI I.F.Value:1.241| Journal DOI: 10.36713/epra2016 \\ ISSN: 2455-7838(Online) EPRA International Journal of Research and Development (IJRD)}

originally derived from the verb temptation, which means "to stir up the heart, to doubt," and to mean "to be under the influence of the devil," "to be under the influence of evil thoughts, and to lose one's peace and health" (OTIL, I, 173). This word is given in the form of vasvăs in ARS (889), and in the textbooks (UAYa, 236; ATG, 339) it is stated that such a word is formed in the weight of filăl (un); The origin of the vowel a, not the vowel $i$ in the first syllable, is explained by the fact that the word is originally formed from the repetition of the word vas taqlid. In colloquial language, the word vasvos is often pronounced as vosvos.

In the process of assimilation of the lexeme Vasvos from Arabic into Uzbek, there was an exchange of vowels in the second syllable of the word: $\mathbf{a} \rightarrow \mathbf{0}$. The nature of this mental illness is medically linked to the devil (jinn). Also, obsessive-compulsive disorder is serious and dangerous and is often characterized by a person committing suicide. For example, Ziyodulla qog'ozqalamni qo'lga olganda, yana shayton vasvasa qildi When Ziyodulla grabbed the pen and paper, the devil tempted him again (H.G'ulom, "Mashal").

JAROHAT - this word from the Arabic language has the form çirăhat (un) (ARS, 124); Accepted in Uzbek by substituting the vowel $\mathrm{i}$ for the vowel a, the vowel a for the vowel o, the vowel hoyi hutti for the vowel h: çirăhat $\rightarrow$ jarăhat $\rightarrow$ jarohat. Charaha, which originally meant "inflicted bodily injury", is a masdar of Chapter I (UAYa, 568), meaning "physical injury", "wound" (OTIL, I, 274). From this word in the Uzbek language the verb with wound (n) is made.

The lexeme of injury is so ingrained in the Uzbek language that it is used in our language just like an Uzbek word. However, the meanings of this word, such as trauma, wound, take the lead. The word is also used in a figurative sense in the language to mean pain, wound, spot in the heart, such as heart injury, tongue injury. For example, Yomon so'z insonning yuragini jarohatlaydi va bu jarohat bir umr ketmaydi. A bad word hurts a person's heart, and that injury doesn't leave a lifetime.

JINNI - this word is a relative adjective derived from the Arabic word chunu, porcelain (ARS, 173), from the word jinn with the Tajik suffix $\mathrm{i}$ (TjRS, 542), and is given in the Tajik dictionary in the form of jinni (TjRS, 516); In Uzbek, the word at the end of the word is replaced by the vowel i: çinn $+\mathbf{i} \rightarrow$ çinni $\rightarrow$ jinni. The word originally meant "insane by the influence of demons"; later, as a result of the development of meaning, he began to express meanings directly related to mental illness, such as "suffering from mental illness" (OTIL, I, 281). In the Uzbek language, the word jinni (insane) is used to form the word jinilik (insanity), and the compound word jinnixona (mental ilnesses hospital) is formed (O'TEL, 129).
This lexeme in Uzbek means a person's mental illness. Therefore, this disease (the same situation was observed in the term vasvos (obsessive-compulsive disorder)) is often understood in connection with a demon, that is, a spiritual being. Spiritually, even such patients are said to be possessed by demons. And such demons are of two kinds, divided into Muslim jinn and kopur jinns. Patients who are possessed or possessed by such demons are treated by the clergy by reciting the words of the Qur'an.

The word jinni (insane) is the name of a disease, and the above complicated aspects of it are that the patient may have lost consciousness from physical or physical exposure, as well as be congenitally mentally weak, disabled. In such cases, associating them with demons and treating them with religious words does not work.

IRSIY - This Arabic word has the form irshiyy (un), In the Uzbek language, it is accepted to replace one of the yy sounds at the end of the word by substituting the consonant hamza for the i sound and the se vowel for the s consonant: biršiyy $\rightarrow$ irsiy $\rightarrow$ irsiy. Chapter I of the verb varisha (ARS, 881), which originally meant "inherited", is a relative adjective derived from the word irš (un) with the suffix -iyy (un), meaning "hereditary disease" (OTIL, I, 333).

IRSIYAT - this Arabic word is an abstract noun with the suffix at (un) as irshiyy (UAYa, 500), meaning "the ability of a living organism to preserve its physical and mental properties and to be passed down from generation to generation" (OTIL, I, 333).

The verb varisa, which means "inherited" in Arabic, is a relative adjective irsiy in Uzbek, which means a type of hereditary disease. In the Uzbek language, both lexemes, i.e., irsiy (hereditary) and irsiyat (hereditary) lexemes, are actually used to refer to an inherited disease in humans or living beings. For example, some diseases in the human body are hereditary and are passed down from ancestors to generations. Odam organizmidagi ayrim kasalliklar irsiy bo'lib, ajdodlardan avlodlarga o'tib boradi. The word irsiyat "heredity" refers not only to the disease, but also to other traits and characteristics that occur in the human body.

KASAL - the word is of Arabic origin and has the form kasal (sick) (un) (ARS, 689); Is the masdar of Chapter I of the verb kasila, which means "lazy", "lazy" (UAYa, 568), which means "laziness", "boredom" in Arabic (ARS, 689); In Uzbek, the word means "disorder of the normal functioning of the body", "sick" (sick, (sick)), "sickness" (sickness), "sick person" (sick) (OTIL, I, 370). With this word in the Uzbek language, the verb disease is an abstract noun, the verb to be sick is formed, and the verb to be sick is formed (O'TEL, 196).

KASALMAND - The word is an adjective derived from the Arabic word kasal (sick) in Uzbek with the 


\section{EPRA International Journal of Research and Development (IJRD)}

Tajik suffix -mand (TjRS, 542), meaning “frequently ill”, "dardchil" (OTIL, I, 371). In the Uzbek colloquial language, the word is also pronounced in the form of diseased, where the consonant $\mathrm{m}$ is replaced by the consonant v: $(\operatorname{lm} \rightarrow \operatorname{lv})$.

KASALNAMO - The Uzbek word is formed by adding the modern base of the verb namo from the Tajik form, which means "look like something" to the Arabic word kasal (sick) (TjRS, 256-257); Meaning as "sick" (OTIL, I, 371).

The lexemes kasal, kasalmand, kasalnamo translated from Arabic into Uzbek, are formed from a single stem. The term kasila "sick" in Arabic means "lazy". In the process of assimilation of this verb into the Uzbek language, the meanings of a person who has lost his health in a certain sense, i.e. sick, ill, were added to it, and a relative quality was formed from the verb in the Uzbek language. Later, new-meaning words were created by adding Tajik -mand, which means repetition, and Tajik -namo, which means similarity, to this acquired relative quality.

MAJRUH - borrowed from Arabic, the word originally has the form maçrûh (un) (ARS, 124); In the Uzbek language, the consonant $\hat{\mathrm{u}}$ is replaced by the vowel $\mathrm{u}$, the consonant hoyi hutti is replaced by the consonant h: maçrûh $\rightarrow$ majruh. In fact, Chapter I of the verb charaha, which means "inflicted physical injury" (ARS, 124), is an adjective of the passive relative (ATG, 148), meaning "injured", "disabled", "disabled" (OTIL, I, 440).

This Arabic lexeme was adopted into the Uzbek language with a certain sound change. In fact, the adjective form of the verb jaraha, which means "physically injured", is mastered in the Uzbek language in the form of a relative adjective meaning "injured", "disabled", "disabled", "wounded". For exemple, Siroj dahboshi ikki majruhni ko'zdan kechirdi (S. Ainiy, “Jallodlar"). For example, Siroj Dahboshi examined two invalids (S. Ayni, "Executioners”).

Today in medicine the term is used in a broader sense in the sense of congenital defects, anomalies in the structure of the organism. Disability occurs as a result of consanguineous marriages or various venereal diseases.

In the example of more than a dozen medical terms from Arabic to Uzbek analyzed above, we can clearly see the specific methods of Uzbek language acquisition in medicine and the lexical and semantic possibilities of our language in this process, the adoption of words from other languages, as well as derivation.

\section{SCIENTIFIC NOVELTY OF THE RESEARCH}

- The study identifies medical terms that have entered and assimilated into Uzbek from other languages, in particular Arabic, as well as the study of the contribution of Arabic for the first time;
- For the first time, etymological and morphological analysis of medical terms borrowed from Arabic into Uzbek was divided into lexical-semantic groups;

- The article provides theoretical and practical coverage of the etymology, morphology, historical and national-cultural features of medical terms in the Uzbek language - linguoculturology;

- The example of medical terms reflects the peculiarities of the Uzbek language and the ways of its development.

\section{CONCLUSION}

First, in the terminology of the Uzbek language, including medical terms, there are terms borrowed from other languages, and they make up a certain percentage. In particular, medical terms learned from Arabic accounted for 1.6 percent of the Medical Encyclopedia (2016).

Second, the emergence, etymology and historical and cultural development of medical terms show that the vocabulary of the Uzbek language has been enriched by learning words from other languages.

Third, when analyzing the lexical-semantic structure of medical terms borrowed from Arabic into Uzbek, the formation of additional meanings in the process of foreign word acquisition, foreign word acquisition - semantic development, the emergence of sound changes - the formation of new words by adding phonetic changes and suffixes - morphological word to make, to create opposite meanings - such phenomena as antonyms were observed.

Our study also showed that derivative meanings arise from the transfer of meaning in medical terms learned from other languages, and at the same time, the Uzbek language has its equivalent meanings.

Fourth, the Uzbek language has its own external and internal capabilities in learning words from other languages, that is, foreign words do not enter our language directly, but certain sound changes, new semantic features occur, are added, resulting in a new meaningful word.

In addition, the above examples show the extralinguistics of the Uzbek language, that is, the specific historical and national-cultural features, etymology of medical terms that have been introduced into the Uzbek language from other languages.

\section{PRACTICAL RECOMMENDATIONS}

As an external factor in the development of the Uzbek language, the acquisition of words from other languages, in particular, medical terms, also contribute. The above-mentioned specific etymology, morphology, history and national-cultural features of the medical terms adopted from Arabic to Uzbek, in fact, reflect the level of vocabulary of the Uzbek language, its scope, 


\section{EPRA International Journal of Research and Development (IJRD)}

richness and diversity, as well as different ways of language development.

Some extralinguistic and intralinguistic phenomena in this process are unique to Uzbek and almost nonexistent in other languages. Knowledge of such linguistic concepts is important for future specialists, language and literature teachers, on the one hand, and for specialists in the field of medicine, on the other hand.

In medicine, first of all, a good knowledge of the semantic nature of each term, the history and etymology of the disease, the mutual differentiation of disease types, gives high efficiency in its treatment. However, it also eliminates some of the ambiguities in medical practice.

Therefore, a more in-depth study and analysis of medical terms learned in Uzbek from other languages will contribute to the development of terminology, lexicology, etymology and other areas of linguistics.

\section{A GRADUAL CONTINUATION OF THE STUDY}

Our next research work will be a continuation of medical terms borrowed from Arabic into Uzbek, as well as lexemes learned from Tajik.

\section{REFERENCES}

1. Arutyunova N.D. (1990). Discourse // Linguistic Encyclopedic Dictionary. Moscow

2. Bobojonov M. (2010) About world languages. Tashkent: "Muharrir".

3. Dadabaev H. (1991). Socio-political and socioeconomic terminology in the Turkic-language written monuments of the XI-XIV centuries. - Tashkent: "Yozuvchi".

4. Eshmominov. A. (2019). Synonymous database of the Uzbek National Corps. : Abstract of dissertation PhD on Philological Sciences, Karshi.

5. Kholmanova Z. (2011). On some terms in Uzbek linguistics. Collection of scientific articles "Linguist". Tashkent.

6. Madvaliev A.P. (2008). Terminological-glossaryannotated dictionary. "Uzbek language and literature" magazine, Issue 6.

7. Nazarov K., Sayfullaeva R., Ubaydullaeva M. (1993). Uzbek language (specialty grammar). Tashkent: "Teacher".

8. Nishonova N.R. (2000). Semantic analysis of the field of archetypal lexemes "animal" in Uzbek language: Abstract of dissertation Candidate of Philological Sciences, Tashkent.

9. Qurbonova M.M. (2001). Formal-functional direction and interpretation of simple sentence construction in Uzbek linguistics: Abstract of dissertation Doctor of Philological Sciences, Tashkent.

10. Rahmatullaev Sh. (2002). Fundamentals of scientific research. Tashkent: "Universitet".

\section{DICTIONARIES}

1. ARS - Baranov H. Arabic-Russian dictionary. Moscow, 1958.

2. BMUS - Usmanhodjaev. A. Big medical educational dictionary. ... Tashkent, 2013

3. Devon - Koshkariy M. Devon lug'atite Turk. Tashkent, 1960-1967

4. DS - Ancient Türkic dictionary. LGR .: 1969

5. KRS - Yudakhin K.K. Kyrgyz-Russian dictionary. Moscow, 1965

6. MS-Medical reference book. Moscow, 1967

7. MHS-Medical nurse directory. Tashkent, 1989

8. PRS - Miller B.V. Persian-Russian dictionary. Moscow, 1953

9. SRYA - Ojegov S. Dictionary of Russian language. Moscow, 1953

10. SSTTN - Budagov L.Z. Comparative dictionary of Turkish-Tatar dialects. - St. Petersburg: 1969 - 1971

11. SE-Encyclopedia of Health. Tashkent, 1983

12. TRD - Tajik-Russian dictionary. Moscow, 1954

13. TE - Encyclopedia of Medicine. Tashkent, 2016

14. UAYA - Kovalev A.A., Sharbatov G.Sh. Arabic language textbook. Moscow, 1960

15. ESTYA - Sevortyan E.V. Etymological Dictionary of Turkic Languages. Moscow, 1974 - 1989

16. O'til-Annotated dictionary of the Uzbek language. 2 volumes. Moscow, 1981

17. Otil - Rahmatullaev Sh. Etymological dictionary of the Uzbek language. Tashkent, "University", 2003 